\title{
Diagnosis of DVT in the emergency department: adherence to guidelines
}

\author{
Christian Skjærbæk \\ From 4th Danish Emergency Medicine Conference \\ Roskilde, Denmark. 25-26 November 2011
}

\section{Background}

Patients presenting with suspected deep vein thrombosis (DVT) are common in the emergency department. Evidence based strategies for the diagnostic evaluation of these patients exists. The diagnosis is based on three criteria: a clinical pre-test probability score (Wells score), D-dimer testing, and ultrasound examination of the deep veins. The aim of our study was to evaluate the adherence to these guidelines in our emergency department.

\section{Methods}

In a retrospective design 252 patients admitted to our department for the suspicion of DVT in 2010 were identified. All patient records were reviewed for the documentation of a pre-test clinical probability score, the result of D-dimer testing and the result of any ultrasound testing. The diagnostic work-up vas categorised as either: appropriate, inappropriate, or indeterminable due to lack of data.

\section{Results}

Wells score was documented in 92 (37\%) cases. D-dimer was measured in $252(100 \%)$ cases and $175(69 \%)$ patients underwent an ultrasound examination. Ultrasound examination was repeated in 18 cases.

The diagnostic work-up could be considered appropriate in $106(42 \%)$ cases. In $53(21 \%)$ cases the diagnostic work-up was inappropriate, in 48 (91\%) cases because an ultrasound examination was not performed although indicated by the guideline and in five $(9 \%)$ cases because an ultrasound examination was performed although not indicated. In 93 (37\%) cases the diagnostic work-up could not be classified as appropriate or inappropriate, in all cases due to lack of documentation of Wells score.

Correspondence: csk@dadlnet.dk

Department of Medicine, Regionshospitalet Viborg, Denmark
We identified three cases were the patient was readmitted and diagnosed with DVT $(\mathrm{n}=2)$ or pulmonary embolism $(n=1)$ less than three months after DVT had been ruled-out. In all three cases the appropriateness of the initial diagnostic work-up could not be determined due to lack of documentation of Wells score.

\section{Conclusion}

We found poor adherence to diagnostic guidelines in our department. Documentation of the pre-test clinical probability is often missing and we found that underutilisation of ultrasound is much more common than over-utilisation. Further more we found some indication that cases of DVT might have been misdiagnosed because Wells score was not applied in the diagnostic work-up.

Published: 16 April 2012

doi:10.1186/1757-7241-19-S2-P12

Cite this article as: Skjærbæk: Diagnosis of DVT in the emergency department: adherence to guidelines. Scandinavian Journal of Trauma, Resuscitation and Emergency Medicine 2012 19(Suppl 2):P12.

Submit your next manuscript to BioMed Central and take full advantage of:

- Convenient online submission

- Thorough peer review

- No space constraints or color figure charges

- Immediate publication on acceptance

- Inclusion in PubMed, CAS, Scopus and Google Scholar

- Research which is freely available for redistribution

\section{(Ciomed Central}

(c) 2012 Skjærbæk; licensee BioMed Central Ltd. This is an Open Access article distributed under the terms of the Creative Commons Attribution License (http://creativecommons.org/licenses/by/2.0), which permits unrestricted use, distribution, and reproduction in any medium, provided the original work is properly cited. 